\title{
Teknik Pola Bilangan dan Hasil Belajar Operasi Pembagian Dalam Pembelajaran Matematika Siswa Madrasah Ibtidaiyah Kelas IV
}

\author{
Kadir dan Hastri Rosiyanti \\ Jurusan Pendidikan Matematika, FITK UIN Jakarta \\ E-mail:dirsal@yahoo.com
}

\begin{abstract}
Abstrak: Tujuan dari penelitian ini adalah untuk mempelajari penggunaan teknik pola bilangan dan kemampuan siswa dalam operasi pembagian di sekolah dasar. Penelitian dilakukan di Madrasah Ibtidaiyah di Ciputat dengan metode quasi eksperimen dengan melibatkan 60 sebagai sampel. Pemilhan sampel menggunakan cluster random sampling. Studi ini menemukan bahwa: 1) hasil belajar operasi pembagian siswa yang menggunakan teknik pola bilangan ini lebih tinggi dari mereka yang menggunakan teknik biasa dan 2) kemampuan siswa yang menggunakan teknik pola bilangan ini lebih baik daripada siswa yang menggunakan teknik biasa. Terbukti dalam penerapannya, siswa dapat mencantumkan bilangan yang dibagi, pembagi, hasil bagi lebih mudah dalam materi operasi pembagian.
\end{abstract}

Kata kunci: teknik pola bilangan, teknik konvensional, operasi pembagian, pembagian dengan satuan, pembagian dengan puluhan, dan pembagian bersisa.

\begin{abstract}
The objective of the present study is to study the effect use of numbers pattern techniques and students' ability in division operation at primary school. The study was conducted in Madrasah Ibtidaiyah in Ciputat with quasi experiment method. There were 60 fourth grade students as the sample of the study, selected by cluster random sampling. The data were gathered by using a test. The result of the study are: 1 ) learning outcome in operation devision of the student who use numbers pattern techniques is higher of those who use conventional technique and 2) ability of the students who use numbers pattern techniques is more good of those who use usual technique, such as student can put a number which are divided, divisor, quotient is more easily in materials division operation.
\end{abstract}

Key words: numbers pattern technique, conventional technique, division operation, devision by unity, decimal, dan radical of devision.

\section{Pendahuluan}

Pendidikan merupakan hal yang sangat penting bagi setiap manusia, karena pendidikan mempunyai peranan yang sangat penting dalam menunjang segala aspek di kehidupan manusia. Salah satunya terlihat dari kemajuan teknologi, sekarang ini penggunaan teknologi semakin canggih, hal ini tidak terlepas dari peran pendidikan itu sendiri, yang memberikan kemudahan-kemudahan bagi manusia.

Kecanggihan teknologi juga memberikan kemudahan pada proses pembelajaran matematika di sekolah, contohnya hampir keseluruhan proses pembelajaran di sekolah guru menggunakan laptop dan LCD (liquid crystal display). Bahkan, tidak hanya laptop dan $L C D$ (liquid crystal display) yang dijadikan alat teknologi dalam proses pembelajaran, melainkan juga internet adalah kecanggihan teknologi yang menjadi acuan para guru dalam mengumpulkan atau menilai tugas siswa dalam pelajaran matematika.

Meskipun kecanggihan teknologi dapat memberikan kemudahan pada pelajaran matematika, tidak menutup kemungkinan bahwa beberapa siswa mengalami kesulitan dalam belajar matematika. Hal ini didukung di dalam buku "Cara Genius Menguasai Tabel Perkalian", Gunawan menuliskan, anak pasti akan berpikir bahwa belajar matematika itu sangat sulit dan membosankan dan akhirnya dia tidak suka dengan pelajaran matematika (Gunawan, 2007:17). 
Pertanyaannya yaitu mengapa banyak sekali anak Indonesia yang tidak menyukai pelajaran matematika, padahal pelajaran itu adalah dasar untuk mempelajari pelajaran lain, misalnya pada pelajaran fisika dan kimia, sebelum belajar pelajaran fisika dan kimia, siswa harus punya dasar kemampuan matematika, bagaimana cara mengoperasikan penjumlahan, pengu-rangan, perkalian, dan pembagian.

Pembagian merupakan operasi aritmatika yang terbilang sulit dikuasai oleh siswa. Kemampuan siswa Sekolah Dasar dan sederajat untuk menghafal pembagian hanya sampai pembagian 2 digit dengan bilangan pembagi 1-9. Penyelesaian pembagian dengan teknik bersusun seperti yang selama ini digunakan, memerlukan waktu yang cukup lama untuk mengerjakannya. Siswa seringkali keliru menempatkan letak angka ratusan, puluhan, atau satuan. Teknik berhitung cepat yang diajarkan di lembaga-lembaga kursus, juga butuh waktu lama (sekitar 1 tahun) bagi siswa untuk menguasai pembagian.

Berdasarkan dari kesulitan siswa dalam mengoperasikan pembagian tersebut maka dengan menggunakan teknik pola bilangan, siswa dapat mengerjakan operasi pembagian dengan mudah dan cepat. Pada buku Polamatika, Premadi mengemukakan bahwa, penggunaan pola bilangan ini terbukti cukup efektif untuk dipelajari siswa karena sangat mudah dan sangat cepat. Hal ini disebabkan siswa hanya menghafalkan satu pola untuk semua soal pembagian sampai 6 digit (bahkan digit tak terbatas) dengan bilangan pembaginya dari 2-99. Jika pola pembagian ini digunakan untuk bilangan yang pembaginya ratusan (101-999) atau bahkan ribuan (10019999), tetap menggunakan satu pola yang sama dengan yang digunakan pada pembagian satuan (Gunawan, 2007).

Berdasarkan latar belakang di atas, masalah dirumuskan sebagai berikut: 1) Apakah terdapat pengaruh dalam penerapan teknik pola bilangan terhadap hasil belajar operasi pembagian bilangan cacah? 2) Bagaimana deskripsi kemampuan siswa dalam materi operasi pembagian bilangan cacah dengan menggunakan teknik pola bilangan?

Berdasarkan permasalahan yang telah diuraikan di atas, tujuan penelitian ini dimaksud- kan untuk menganalisis pengaruh penggunaan teknik pola bilangan terhadap hasil belajar matematika serta perbedaan kemampuan siswa yang menggu-nakan teknik pola bilangan dan teknik biasa (bersusun).

\section{Kajian Literatur \\ Pengertian Hasil Belajar Matematika}

Belajar adalah suatu proses yang memperoleh pengetahuan. Pengetahuan yang diperoleh tidak hanya dari sekolah melainkan juga dari luar sekolah. Pengetahuan yang diperoleh manusia bisa didapatkan dari setiap jenjang pendidikan, jadi bisa dikatakan bahwa belajar merupakan proses kegiatan yang dapat dilakukan oleh manusia pada jenjang pendidikan dasar sampai jenjang perkuliahan. Belajar adalah kegiatan yang berproses dan merupakan unsur yang sangat fundamental dalam setiap penyelenggaraan jenis dan jenjang pendidikan (Syah, 2007). Pengalaman yang lalu pada proses pembelajaran adalah konsep awal yang sudah dimiliki oleh siswa dan guru sebagai fasilitator membantu siswa menanamkan atau menambah pengetahuan baru dari suatu materi, sehingga pengetahuan yang dimiliki oleh siswa berkembang.

Ausubel menyarankan bahwa guru mencoba mengikatkan informasi baru ke dalam struktur yang telah direncanakan di dalam permulaan pelajaran, dengan cara mengingatkan siswa bahwa rincian yang bersifat spesifik itu berkaitan dengan gambaran informasi yang bersifat umum. Pada akhir pembelajaran siswa diminta mengajukan pertanyaan pada diri sendiri mengenai tingkat pemahamannya terhadap pelajaran yang baru dipelajari, menghubungkannya dengan pengetahuan yang telah dimiliki dan pengorganisasian materi pembelajaran dan juga memberikan pertanyaan kepada siswa dalam rangka keluasan pemahaman siswa tentang isi pelajaran. Belajar bermakna merupakan proses dikaitkannya informasi baru pada konsep-konsep relevan yang terdapat dalam struktur kognitif seseorang (Trianto, 2009).

Matematika merupakan suatu ilmu yang menggunakan lambang-lambang matematika. Ilmu matematika bukanlah sekadar berhitung, tetapi matematika merupakan kegiatan menemukan dan mempelajari pola serta hubungan. 
Matematika memiliki simbol, gambar, atau pola yang bersifat efisien dan padat makna.

Dari berbagai macam bilangan terdapat salah satu macam bilangan, yaitu bilangan cacah. Bilangan cacah adalah subbagian dari bilangan kompleks, real, rasional serta bilangan bulat. Bilangan cacah adalah bilangan asli yang ditambah unsur bilangan nol (Supatmono, 2009). Jadi, yang termasuk bilangan cacah yaitu 0, 1, 2, 3, dan seterusnya.

Hasil belajar matematika adalah suatu nilai (angka) yang dicapai oleh siswa setelah melakukan proses kegiatan belajar matematika dan pengetahuan tentang matematika yang dimiliki oleh siswa setelah mengalami proses belajar matematika di mana tingkah laku itu tampak dalam bentuk perbuatan yang dapat diamati dan diukur.

\section{Teknik Pola Bilangan}

Teknik perhitungan pembagian pada umumnya yang digunakan adalah dengan cara bersusun. Cara bersusun bukanlah satu-satunya cara dalam menyelesaikan suatu operasi hitung pembagian, tetapi ada teknik lain yang dapat digunakan dalam menyelesaikan operasi hitung pembagian, yaitu teknik pola bilangan. Teknik pola bilangan adalah teknik berhitung yang tergolong cepat dan mudah. Dengan menggunakan teknik pola bilangan ini, siswa akan lebih mudah untuk memahami suatu operasi hitung. Penggunaan pola bilangan ini terbukti cukup efektif untuk dipelajari siswa karena sangat mudah dan sangat cepat (Premadi, 2007).

Pola bilangan ini diperlukan kolom bantu. Kolom ini adalah alat bantu perhitungan operasi hitung, seperti pada operasi pembagian. Adapun contoh kolom teknik pola bilangan (Premadi, 2007).

Setiap model pembelajaran, strategi, metode maupun teknik memiliki kelebihan dan kelemahan masing-masing, seperti teknik pola bilangan.

\section{Keunggulan Teknik Pola Bilangan}

Teknik pola bilangan mempunyai cara yang berbeda dari perhitungan cara bersusun dalam meyelesaikan operasi hitung pembagian, sehingga membuat siswa tidak bosan dalam belajar operasi hitung. Keunggulan tersebut karena teknik pola bilangan: a) mempunyai kolom untuk menyelesaikan perhitungan operasi pembagian, kolom dibentuk kotak-kotak seperti sebuah permainan, dengan hal ini siswa akan senang, karena ia merasa tidak terbebani dalam situasi belajar matematika, bahkan dari sini bisa dijadikan suatu permainan operasi pembagian yang menarik dengan alat bantu kolom; b) tidak melakukan sistem simpan yang dilakukan dengan metode bersusun, dengan ini siswa tidak akan keliru dalam menghitung; dan c) tidak menggunakan alat bantu hitung, seperti sempoa.

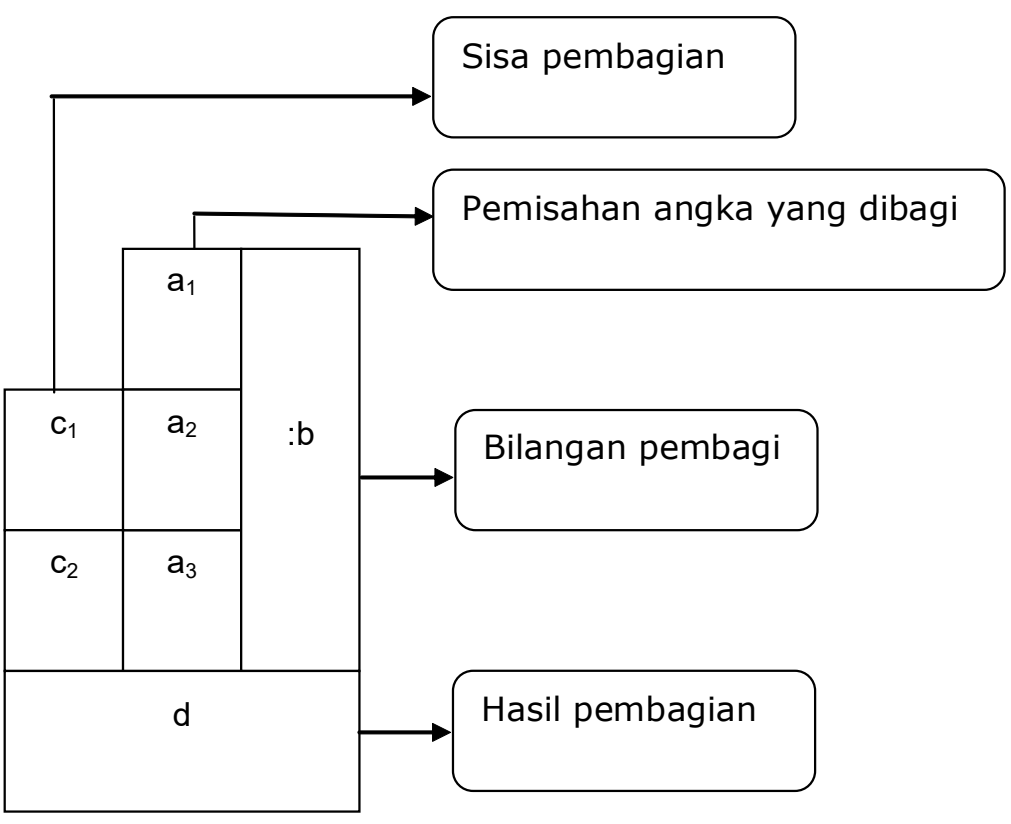

Diagram 1. Kolom Pola Bilangan Pembagian 
Kelemahan Teknik Pola Bilangan

Kelemahan dari teknik pola bilangan, antara lain:

a) teknik ini hanya cocok untuk siswa sekolah dasar dan sedarajatnya maka tidak bisa dikembangkan ke jenjang yang lebih tinggi, b) siswa harus hapal perkalian 1 sampai perkalian 10, dan c) siswa harus hapal terlebih dahulu pembagian sampai 100 .

\section{Pembagian Bilangan Cacah dengan Pola Bilangan}

Pembagian bilangan matematika sesuatu yang sulit bagi sebagian besar siswa SD, SMP, maupun SMA. Mereka seringkali mengalami kesulitan untuk menyelesaikan pembagian, dengan pola bilangan, semua persoalan pembagian bilangan akan menjadi mudah.

\section{Pembagian dengan Satuan \\ Dengan bilangan pertama bisa dibagi}

$$
56: 2=\ldots
$$

Langkah pertama

Pisahkan angka pada bilangan yang dibagi, kemudian masukkan dalam kolom pola bilangan.
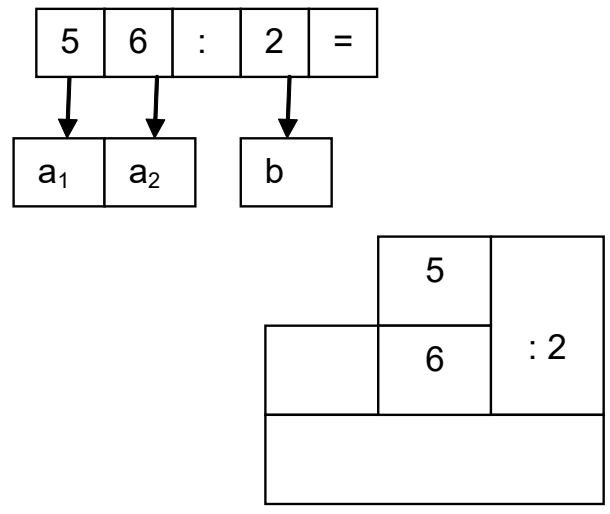

\section{Langkah kedua}

1) Bagilah nilai $a_{1}$ dengan bilangan pembagi $b$

2) Tuliskan hasilnya di kolom d dan sisanya di kolom $\mathrm{c}_{1}$

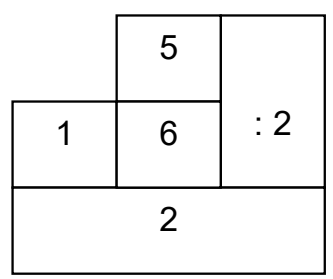

Langkah ketiga

1) Gabungkan kolom $c_{1}$ dengan kolom sebelahnya $\left(a_{2}\right)$.

2) Hasil penggabungan bagilah dengan nilai kolom b. kemudian hasilnya di kolom d (sebelah hasil pertama).

Hasil penggabungan 1 dan 6 adalah 16, sehingga $16: 2=8$

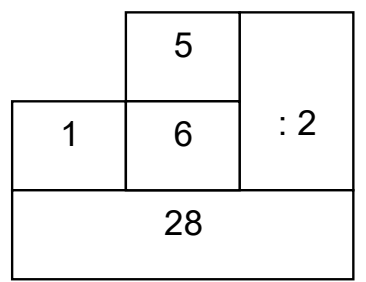

Langkah keempat

Hasil pembagian dapat diketahui di kolom d, nilainya adalah 28

Jadi, $56: 2=28$

\section{Dengan bilangan pertama tidak bisa dibagi}

$$
148: 2=\ldots
$$

Langkah pertama

Pisahkan angka pada bilangan yang dibagi, kemudian masukkan dalam kolom pola bilangan. Catatan: Jika angka hasil pemisahan bilangan tidak dapat dibagi dengan bilangan pembagi maka angka tersebut digabung dengan angka sesudahnya.
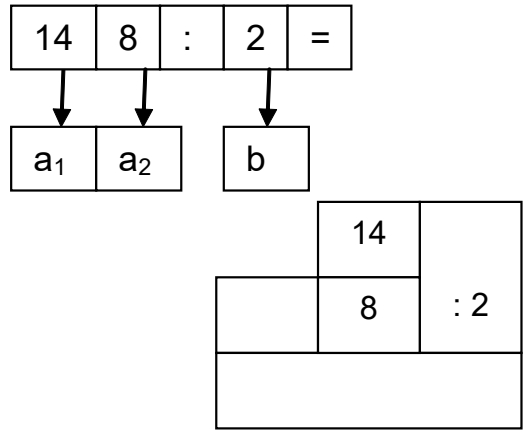

Langkah kedua

1) Bagilah nilai $a_{1}$ dengan bilangan pembagi $b$

2) Tuliskan hasilnya di kolom d dan sisanya di kolom $\mathrm{c}_{1}$.

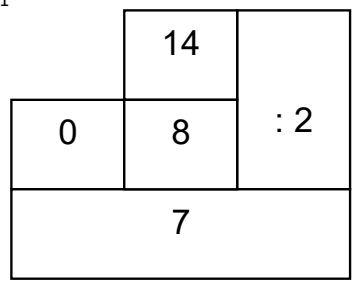


Langkah ketiga

1) Gabungkan kolom $c_{1}$ dengan kolom sebelahnya $\left(a_{2}\right)$.

2) Hasilnya penggabungan, bagilah dengan nilai kolom b. kemudian hasilnya tulis di kolom d (sebelah hasil pertama).

Hasil penggabungan 0 dan 8 adalah 08 atau 8 . Sehingga $8: 2=4$

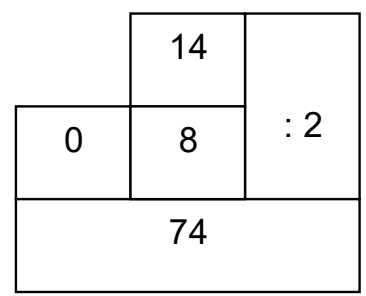

Langkah keempat

Hasil pembagian dapat diketahui di kolom d, nilainya adalah 74 .

Jadi, $148: 2=74$.

\section{Pembagian dengan Puluhan}

Setelah mempelajari pembagian bilangan dengan satuan, tahap selanjutnya yaitu mempelajari pembagian dengan puluhan.

$$
672: 12=\ldots
$$

Langkah pertama

Pisahkan angka pada bilangan yang dibagi, kemudian masukkan dalam kolom pola bilangan.
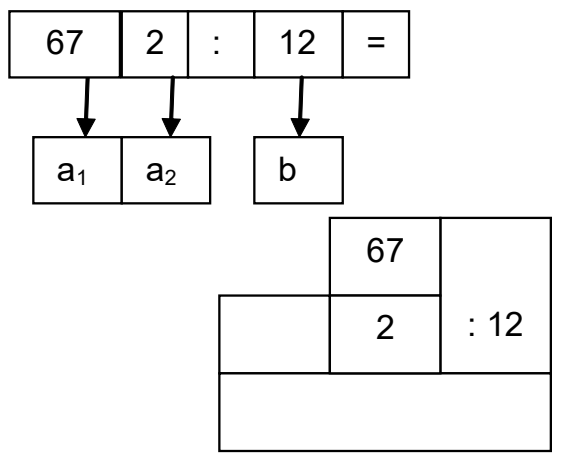

Langkah kedua

1) Bagilah nilai $a_{1}$ dengan bilangan pembagi (b)

2) Tuliskan hasilnya di kolom d dan sisanya di kolom $\mathrm{c}_{1}$

$67: 12=5$ sisa 7

\begin{tabular}{|l|l|l|}
\cline { 2 - 3 } \multicolumn{1}{l|}{} & 67 & \\
\hline 7 & 2 & $: 12$ \\
\hline \multicolumn{3}{|c|}{5} \\
\hline
\end{tabular}

Langkah ketiga

1) Gabungkan kolom c1 dengan kolom sebelahnya (a2).

2) Hasil penggabungan bagilah dengan nilai kolom b, kemudian hasilnya tulis di kolom $d$ (sebelah hasil pertama).

Hasil penggabungan 7 dan 2 adalah 72. Sehinga $72: 12=6$

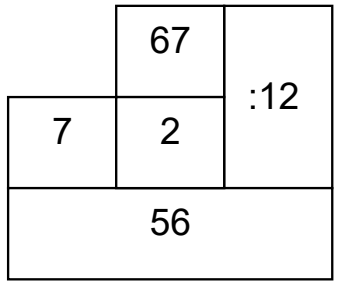

Langkah keempat

Hasil pembagian dapat diketahui di kolom d, nilainya 56. Jadi, $672: 12=56$.

\section{Pembagian Bersisa}

Pembagian bersisa adalah pembagian yang menghasilkan sisa. Pembagian menghasilkan sisa terjadi jika bilangan tersebut tidak habis dibagi.

$$
89: 7=\ldots
$$

Langkah pertama

Pisahkan angka pada bilangan yang dibagi, kemudian masukkan dalam kolom pola bilangan.
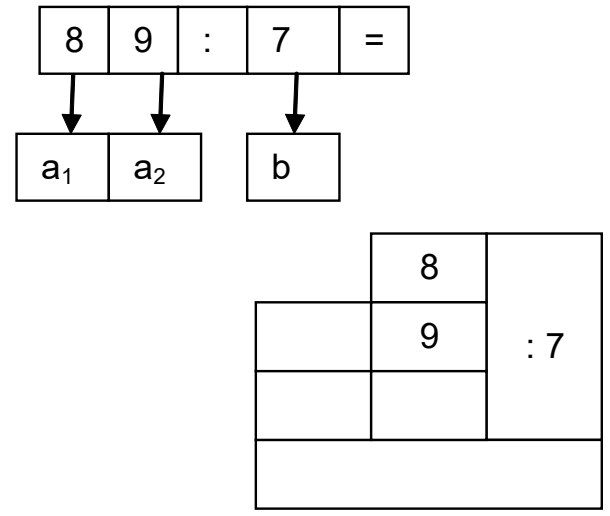

\section{Langkah kedua}

1) Bagilah nilai $a_{1}$ dengan bilangan pembagi (b)

2) Tuliskan hasilnya di kolom d dan sisanya di kolom $\mathrm{c}_{1}$.

$8: 7=1$ sisa 1

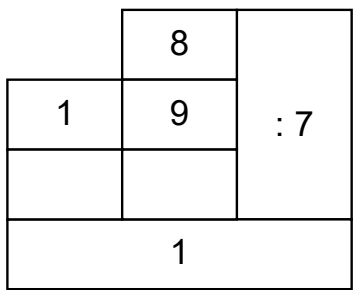


Langkah ketiga

1) Gabungkan kolom c1 dengan kolom sebelahnya (a2).

2) Hasil penggabungan bagilah dengan nilai kolom b. kemudian hasilnya tulis di kolom d (sebelah hasil pertama).

Hasil penggabungan 1 dan 9 adalah 19. Sehingga $19: 7=2$ sisa 5

\begin{tabular}{|c|c|c|}
\hline & 8 & \multirow{3}{*}{$: 7$} \\
\hline 1 & 9 & \\
\hline 5 & & \\
\hline & 12 & \\
\hline
\end{tabular}

\section{Langkah keempat}

1) Karena bilangan di kolom a (bilangan utama) tidak ada, sedangkan di kolom c masih ada sisa, berarti pembagian tersebut menghasilkan sisa pembagian yaitu 5 .

2) Hasil pembagian dapat diketahui di kolom d, nilainya 12 dan sisanya 5 atau dapat dituliskan dengan $12 \frac{5}{7}$. Jadi, $89: 7=12 \frac{5}{7}$

\section{Kerangka Berpikir}

Penerapan teknik pola bilangan yang diajarkan kepada siswa dapat menfasilitasi siswa dalam menyelesaikan soal pembagian. Penggunaan pola bilangan cukup efektif untuk dipelajari siswa karena menyediakan kolom untuk menyelesaikan perhitungan, operasi pembagian dan kotak-kotak sebagai sebuah permainan.

Secara grafis kerangka berpikir yang dilakukan oleh peneliti dapat digambarkan dengan bentuk diagram 2 .
Melalui teknik pola bilangan, siswa diduga dapat meningkatkan hasil belajar matematika, sehingga hasil belajar operasi pembagian siswa dalam pembelajaran teknik pola bilangan menjadi lebih baik dibandingkan pembelajaran teknik bersusun.

\section{Metode Penelitian}

\section{Tempat dan Waktu Penelitian}

Penelitian ini dilakukan di Madrasah Ibtidaiyah (MI) Pembangunan Ciputat. Waktu penelitian dimulai dari Juli 2010 sampai dengan Agustus 2010 Semester I Tahun Pelajaran 2010/2011.

\section{Populasi dan Sampel}

Populasi penelitian adalah seluruh siswa kelas IV Madrasah Ibtidaiyah (MI) Pembangunan. Pemilihan sampel dilakukan dengan teknik Cluster Random Sampling, dengan mengambil dua kelas secara acak dari 8 kelas yang memiliki karakteristik yang sama. Kelas eksperimen yaitu kelas IV-H sebanyak 30 orang yang diajar dengan menggunakan teknik pola bilangan kelas kontrol sebanyak 30 orang, yaitu kelas IV-G menggunakan teknik bersusun (konvensional).

\section{Metode dan Desain Penelitian}

Metode penelitian yang digunakan dalam peneltian ini adalah metode quasi eksperimen. Rancangan atau desain penelitian yang digunakan untuk menerapkan perlakuan pembelajaran adalah Randomized Control Group Design. Rancangan penelitian dinyatakan pada tabel 1.

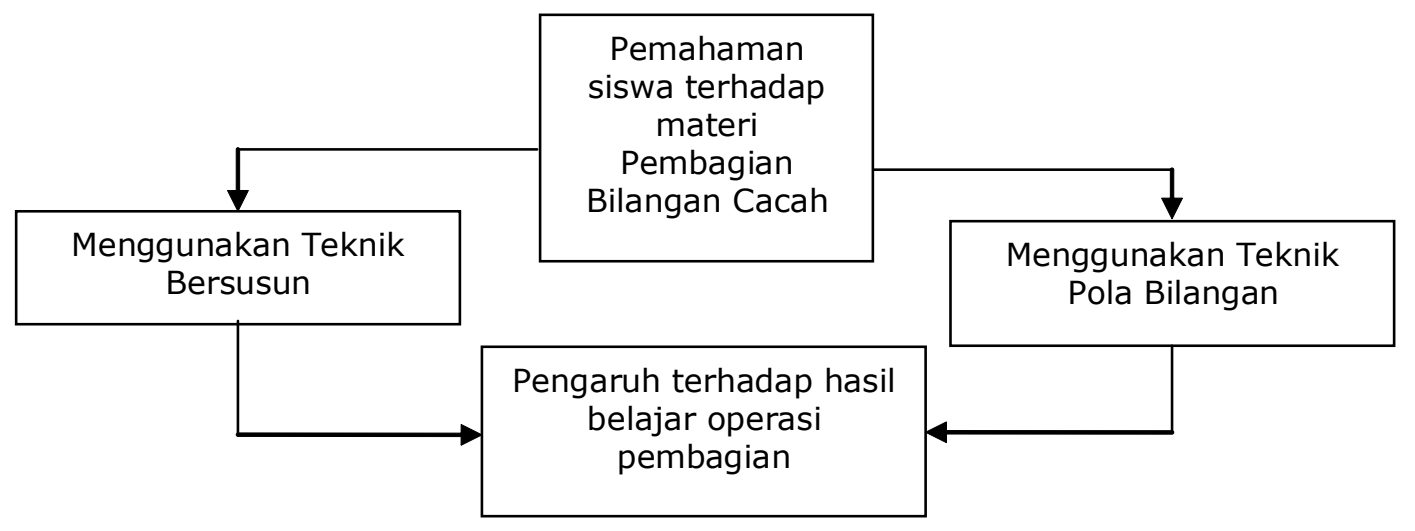

Diagram 2. Kerangka Berpikir 
Tabel 1. Rancangan Penelitian

\begin{tabular}{|c|c|c|}
\hline Kelompok & Variabel Bebas & Tes Akhir \\
\hline$(\mathrm{R})_{\mathrm{E}}$ & $\mathrm{X}_{\mathrm{E}}$ & $\mathrm{Y}$ \\
\hline$(\mathrm{R})_{\mathrm{K}}$ & $\mathrm{X}_{\mathrm{K}}$ & $\mathrm{Y}$ \\
\hline
\end{tabular}

Keterangan:

$\mathrm{R}$ : Pemilihan secara acak kelas

$\mathrm{X}_{\mathrm{E}}$ : Perlakuan dengan teknik pola bilangan.

$X_{k}$ : Perlakuan dengan teknik pola bersusun.

$Y \quad$ : Tes akhir

\section{Instrumen}

Instrumen yang digunakan untuk mengukur hasil belajar operasi pembagian adalah tes objektif bentuk pilihan ganda sebanyak 21 butir soal, dengan empat pilihan yang mempunyai skala ukur berupa skor 1 untuk jawaban yang benar dan diberi skor 0 untuk jawaban yang salah. Soal-soal tersebut mengacu pada aspek kognitif yang meliputi pemahaman dan aplikasi.

Instrumen diujicobakan terlebih dahulu untuk menentukan validitas, daya pembeda, dan taraf kesukaran butir soal sebelum digunakan. Koefisien reliabilitas dihitung dengan menggunakan rumus Kuder-Richardson (KR-20). Dari hasil perhitungan koefisien reliabilitas sebesar 0,904 atau tergolong sangat baik. Dengan demikian, instrumen yang digunakan dalam penelitian ini memadai untuk digunakan sebagai alat untuk menjaring data hasil belajar operasi pembagian. Instrumen nontes berupa lembar observasi digunakan untuk melihat proses pembelajaran berlangsung. Pengamatan dilakukan untuk menilai aktivitas siswa selama proses pembelajaran.

\section{Teknik Analisis Data}

Teknik analisis yang digunakan dalam penelitian ini meliputi teknik analisis deskriptif dan teknik analisis inferensial. Teknik analisis deskriptif digunakan untuk memperoleh gambaran tentang ukuran kecenderungan memusat dan menyebarnya data meliputi rata-rata, median, modus, rentang, standar deviasi, varians dan kemiringan. Teknik analisis inferensial digunakan untuk membuat simpulan berdasarkan hasil pengujian hipotesis. Teknik analisis inferensial yang digunakan dalam penelitian ini adalah teknik analisis statistik uji - t dengan taraf signifikan $\alpha=0,05$.
Sebelum dilakukan pengujian hipotesis terlebih dahulu dilakukan pengujian normalitas dan kesamaan varians (uji homogenitas). Pengujian normalitas dilakukan dengan menggunakan uji Chi-Kuadrat. Uji homogenitas dilakukan dengan Uji Fisher. Setelah memenuhi kedua persyaratan ini, selanjutnya pengujian hipotesis statistik dilakukan. Adapun rumusan hipotesis yang akan diuji adalah.

$$
\begin{aligned}
& \mathrm{H}_{0}: \mu_{1} \text { d" } \mu_{2} \\
& \mathrm{H}_{1}: \mu_{1}>\mu_{2}
\end{aligned}
$$

\section{Hasil Penelitian dan Bahasan Hasil Belajar Operasi Pembagian dengan Teknik Pola Bilangan}

Berdasarkan data hasil belajar matematika pada materi operasi pembagian kelompok siswa yang diajar menggunakan teknik pola bilangan diperoleh nilai dari 29 sampai dengan 100 dengan nilai rata-rata sebesar 67,70 , modus 71,70 median 69,64 , varians sebesar 413,96 dan standar deviasi sebesar 20,35. Tingkat kemiringan $\left(\alpha_{3}\right)-0,29$, atau maka kurva landai kiri atau kurva positif dan ketajaman/kurtosis $\left(\alpha_{4}\right)$ 1,76 atau kurva berbentuk platikurtik (mendatar) sehingga nilai rata-rata tersebar secara merata. Hasil analisis deskriptif disajikan pada Tabel 2.

Dari hasil analisis pada Tabel 2 dapat dilihat bahwa dari 30 siswa di kelas yang diajar dengan teknik pola bilangan diperoleh nilai di atas ratarata sebanyak $60 \%$ yaitu 18 siswa, sedangkan yang mendapat nilai di bawah rata-rata sebanyak $40 \%$ yaitu 12 siswa.

Secara visual deskripsi data hasil belajar operasi pembagian kelas eksperimen disajikan pada Histogram dan Poligon Frekuensi Gambar 1.

Dari Gambar 1 dapat dilihat bahwa frekuensi absolut tertinggi berada pada rentang 64,5 76,5 , terendah berada pada rentang $28,5-40,5$ , 40,5 - 52,5 dan rentang 52,5 - 64,5. Median data terletak pada rentang 64,5 - 76,5. Gambar di atas memiliki kemiringan sebesar $-0,29$ atau memiliki kemiringan yang negatif. Dengan demikian, data hasil belajar operasi bilangan siswa yang diberi teknik pola bilangan memiliki kecenderungan mengelompok di atas rata-rata empirik. 
Tabel 2. Distribusi Frekuensi Hasil Belajar Matematika Siswa Kelas Eksperimen

\begin{tabular}{|c|c|c|c|c|}
\hline Nilai & $\begin{array}{c}\text { Titik } \\
\text { Tengah }\end{array}$ & $\begin{array}{c}\text { Frekuensi } \\
\text { Absolut }\end{array}$ & $\begin{array}{c}\text { Frekuensi } \\
\text { Kumulatif }\end{array}$ & $\begin{array}{c}\text { Frekuensi } \\
\text { Relatif(\%) }\end{array}$ \\
\hline $29-40$ & 34,5 & 4 & 4 & 13,33 \\
\hline $41-52$ & 46,5 & 4 & 8 & 13,33 \\
\hline $53-64$ & 58,5 & 4 & 12 & 13,33 \\
\hline $65-76$ & 70,5 & 7 & 19 & 23,33 \\
\hline $77-88$ & 82,5 & 5 & 24 & 16,67 \\
\hline $89-100$ & 94,5 & 6 & 30 & 20,00 \\
\hline Jumlah & - & 30 & - & 100 \\
\hline
\end{tabular}

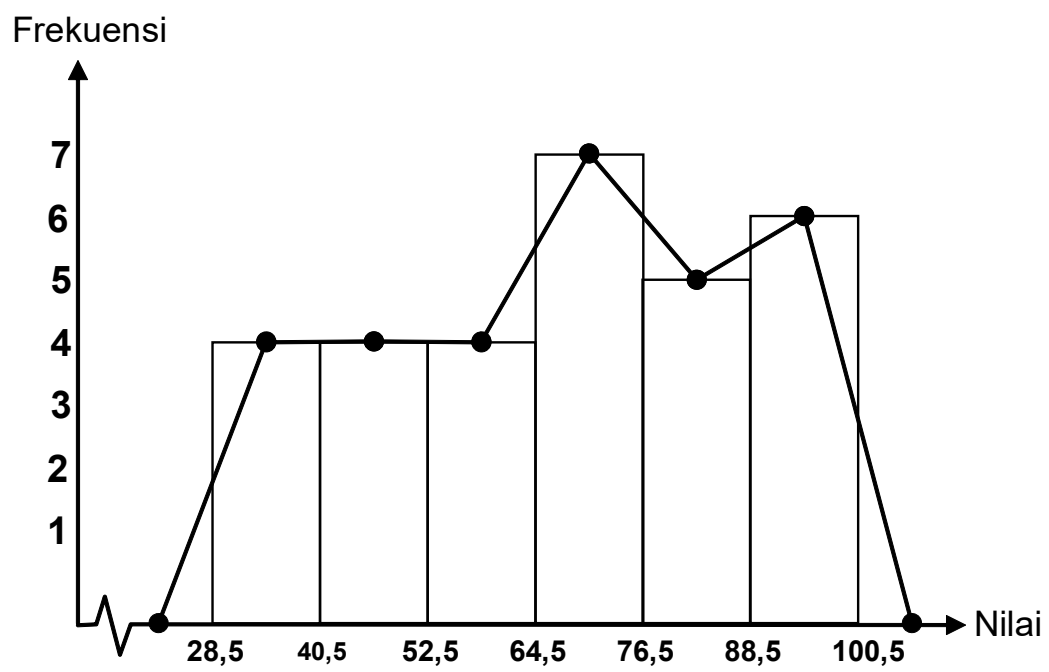

Gambar 1. Histogram dan Poligon Hasil Belajar Matematika Siswa dengan Teknik Pola Bilangan

\section{Hasil Belajar Operasi Pembagian dengan Teknik Bersusun}

Berdasarkan data hasil belajar matematika pada materi operasi pembagian kelompok siswa yang diajar menggunakan teknik bersusun diperoleh rentangan nilai dari 15 sampai dengan 100 dengan nilai rata-rata sebesar 54,50, modus 49,73 median 52,77, varians sebesar 414,05 dan standar deviasi sebesar 20,35. Kemiringan ) 0,26 berharga positif maka kurva agak landai di kanan, sedangkan ketajaman/ kurtosis 2,32 < 3 dengan kurva berbentuk platikurtik (mendatar) sehingga nilai rata-rata tersebar secara merata. Hasil analisis deskriptif disajikan pada tabel Tabel 3.

Dari hasil analisis pada tabel 3 dapat dilihat bahwa dari 30 siswa di kelas kontrol yang menggunakan teknik bersusun diperoleh nilai di atas rata-rata sebanyak 43,33\%, yaitu 13 siswa,

Tabel 3. Distribusi Frekuensi Hasil Belajar Matematika Siswa

\begin{tabular}{|c|c|c|c|c|}
\hline Nilai & $\begin{array}{c}\text { Titik } \\
\text { Tengah }\end{array}$ & $\begin{array}{c}\text { Frekuensi } \\
\text { Absolut }\end{array}$ & $\begin{array}{c}\text { Frekuensi } \\
\text { Kumulatif }\end{array}$ & $\begin{array}{c}\text { Frekuensi } \\
\text { Relatif(\%) }\end{array}$ \\
\hline $11-25$ & 18 & 3 & 3 & 10,00 \\
\hline $26-40$ & 33 & 3 & 6 & 10,00 \\
\hline $41-55$ & 48 & 11 & 17 & 36,67 \\
\hline $56-70$ & 63 & 6 & 23 & 20,00 \\
\hline $71-85$ & 78 & 5 & 28 & 16,67 \\
\hline $86-100$ & 93 & 2 & 30 & 6,67 \\
\hline Jumlah & - & 30 & - & 100 \\
\hline
\end{tabular}


sedangkan yang mendapat nilai di bawah ratarata sebanyak 56,67\% yaitu 17 siswa. Secara visual deskripsi data hasil belajar operasi pembagian kelas kontrol disajikan pada Histogram dan Poligon Frekuensi Gambar 2. matematika antara kelas eksperimen dan kelas kontrol ditunjukkan pada Tabel 4.

\section{Pengujian Persyaratan Analisis}

Sebelum dilakukan pengujian hipotesis, terlebih

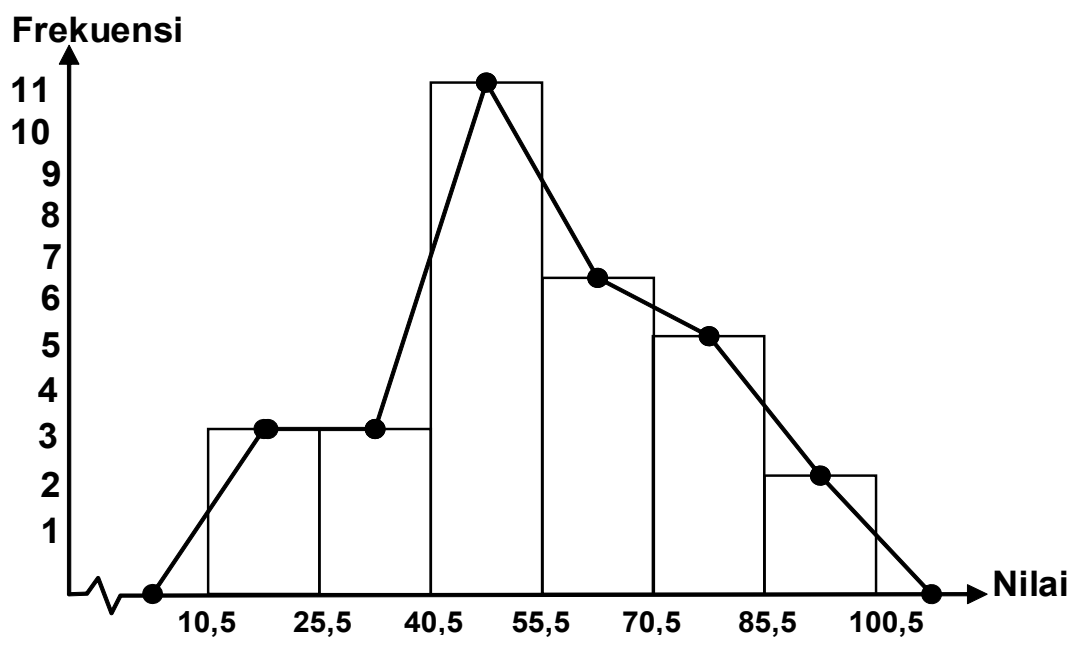

Gambar 2. Histogram dan Poligon Hasil Belajar Operasi Pembagian dengan Teknik Bersusun

Dari Gambar 2 dapat dilihat bahwa frekuensi absolut tertinggi berada pada rentang 40,5 55,5 , frekuensi absolut terendah berada pada rentang $85,5-100,5$. Median data terletak pada rentang 40,5 - 55,5. Gambar histogram dan poligon di atas memiliki kemiringan sebesar 0,26 atau memiliki kemiringan yang positif. Dengan demikian, data hasil belajar operasi pembagian siswa yang diberi teknik bersusun memiliki kecenderungan mengelompok di bawah rata-rata empirik.

\section{Perbandingan Hasil Belajar Matematika Antara Kelas Eksperimen dan Kelas Kontrol}

Secara garis besar perbandingan hasil belajar dahulu dilakukan pengujian persyaratan analisis, meliputi uji normalitas dan homogenitas. Pengujian normalitas dilakukan dengan menggunakan Uji Chi-Kuadrat. Hasil pengujian normalitas data kelas eksperimen dan kelas kontrol disajikan pada Tabel 5.

Dari hasil analisis persyaratan normalitas pada Tabel 5 diperoleh harga $\chi^{2}$ hitung $<_{\text {tabel }}$ pada $\alpha=0,05$ maka dapat disimpulkan bahwa kedua data sampel berasal dari populasi berdistribusi normal. Selanjutnya, uji persyaratan homogenitas varians data kelompok eksperimen dan control dilakukan dengan menggunakan uji Fisher. Hasil pengujian homogenitas dapat dilihat pada tabel 6.

Tabel 4. Perbandingan Hasil Belajar Operasi Pembagian Kelas Eksperimen dan Kelas Kontrol

\begin{tabular}{|c|c|c|}
\hline Statistika & Kelas Eksperimen & Kelas Kontrol \\
\hline Jumlah sampel(N) & 30 & 30 \\
\hline Mean $(\bar{X})$ & 67,70 & 54,50 \\
\hline Median(Me) & 69,64 & 52,77 \\
\hline Modus(Mo) & 71,70 & 49,73 \\
\hline Varians(S $\left.{ }^{2}\right)$ & 413,96 & 414,05 \\
\hline Simpangan baku(S) & 20,35 & 20,35 \\
\hline Kemiringan $\left(\alpha_{3}\right)$ & $-0,29$ & 0,26 \\
\hline Ketajaman/kurtosis $\left(\alpha_{4}\right)$ & 1,76 & 2,32 \\
\hline
\end{tabular}


Tabel 5. Hasil Pengujian Normalitas

\begin{tabular}{|c|c|c|c|c|}
\hline Kelas & Sampel & $\chi^{2}$ hitung & $\chi^{2}$ tabel & Kesimpulan \\
\hline Eksperimen & 30 & 6,17 & 7,81 & Normal \\
\hline Kontrol & 30 & 3,16 & 7,81 & Normal \\
\hline
\end{tabular}

Dari hasil analisis pada tabel 6 , diperoleh $\mathrm{F}$ hitung $<\mathrm{F}_{\text {tabel }}(1,00<2,10)$ maka $_{0}$ diterima, artinya kedua varians populasi homogen.

\section{Pengujian Hipotesis}

Pengujian hipotesis tentang perbedaan parameter rata-rata hasil belajar operasi pembagian dilakukan dengan menggunakan statistika uji-t. Dari hasil perhitungan diperoleh
Perbedaan rata-rata hasil belajar operasi pembagian antara kedua kelas tersebut menunjukkan bahwa pembelajaran dengan menggunakan teknik pola bilangan lebih baik daripada pembelajaran dengan menggunakan teknik bersusun. Hal tersebut didukung oleh hasil pengamatan selama berlangsungnya pembelajaran. Siswa lebih semangat dalam proses pembelajaran menggunakan teknik pola bilangan.

Tabel 6. Hasil Pengujian Homogenitas

\begin{tabular}{|c|c|c|c|c|c|}
\hline Kelas & $\begin{array}{c}\text { derajat } \\
\text { bebas }\end{array}$ & $\begin{array}{c}\text { Varians } \\
\left(\mathrm{s}^{2}\right)\end{array}$ & $\mathrm{F}_{\text {hitung }}$ & $\mathrm{F}_{\text {tabel }}$ & Kesimpulan \\
\hline Eksperimen & 30 & 413,96 & 1,00 & 2,10 & Terima $\mathrm{H}_{0}$ \\
\hline Kontrol & 30 & 414,05 & & & \\
\hline
\end{tabular}

harga $\mathrm{t}_{\text {hitung }}=2,51$, untuk $\alpha=0,05$ dan derajat kebebasan $(d b=58)$ diperoleh harga $t_{\text {tabel }}=2,00$. Hasil perhitungan uji hipotesis disajikan pada Tabel 7.

Dari hasil analisis pada Tabel 7 terlihat bahwa $\mathrm{t}_{\text {hitung }}$ lebih besar dari $\mathrm{t}_{\text {tabel }}(2,51>2,00)$ maka dapat disimpulkan bahwa $\mathrm{H}_{0}$ ditolak. Hal ini berarti hasil belajar operasi pembagian siswa yang diajar teknik pola bilangan lebih tinggi daripada kelas siswa yang diajar menggunakan teknik bersusun.

\section{Pembahasan Hasil Penelitian}

Berdasarkan deskripsi data temuan dan pengujian hipotesis menunjukkan bahwa hasil belajar operasi pembagian siswa yang diajar dengan teknik pola bilangan ternyata lebih tinggi daripada siswa yang diajar dengan teknik bersusun.
Pengamatan terhadap siswa pada kelas eksperimen dengan lembar observasi dilakukan selama proses pembelajaran matematika berlangsung. Pengamatan dilakukan pada pertemuan kedua dan ketujuh pada kelas eksperimen bertujuan untuk mengetahui keaktifan siswa selama proses pembelajaran, yaitu pada saat siswa mulai pertama kali menggunakan teknik pola bilangan dalam menyelesaikan soal operasi pembagian. Pengamatan pada pertemuan ketujuh bertujuan untuk melihat kemajuan siswa setelah menggunakan teknik pola bilangan pada materi operasi pembagian. Deskriptor dan hasil pengamatan disajikan pada Tabel 8 .

Rekapitulasi hasil pengamatan proses pembelajaran siswa disajikan pada Tabel 9.

Tabel 7. Hasil Pengujian Hipotesis

\begin{tabular}{|c|c|c|c|}
\hline$d b$ & $\mathrm{t}$ hitung & $\mathrm{t}$ tabel & Kesimpulan \\
\hline 58 & 2,51 & 2,00 & Tolak $\mathrm{H}_{0}$ \\
\hline
\end{tabular}


Tabel 8. Deskriptor Penilaian Observasi

\begin{tabular}{|c|c|c|c|c|c|}
\hline No & Aspek ${ }^{\text {Skor }}$ & 1 & 2 & 3 & 4 \\
\hline 1 & $\begin{array}{l}\text { Memperhatikan } \\
\text { penjelasan guru }\end{array}$ & $0-8$ orang & 9-17 orang & $18-25$ orang & $25-32$ orang \\
\hline 2 & $\begin{array}{l}\text { Pertanyaan/tanggapan } \\
\text { teman }\end{array}$ & $0-8$ orang & 9-17 orang & $18-25$ orang & $25-32$ orang \\
\hline 3 & $\begin{array}{l}\text { Bertanya pada guru } \\
\text { tentang materi yang } \\
\text { kurang dipahami }\end{array}$ & $\begin{array}{c}\text { Tidak ada } \\
\text { pertanyaan } \\
\text { dari siswa, } \\
\text { jika } \\
\text { ditanya } \\
\text { kembali } \\
\text { oleh guru, } \\
\text { mereka } \\
\text { tidak bisa } \\
\text { menjawab }\end{array}$ & $\begin{array}{c}\text { Masih ada siswa } \\
\text { tidak bertanya } \\
\text { pada saat jika } \\
\text { kurang paham, } \\
\text { dan siswa } \\
\text { bertanya } \\
\text { setelah } \\
\text { diberikan LKS }\end{array}$ & $\begin{array}{c}\text { Mereka } \\
\text { bertanya } \\
\text { setelah guru } \\
\text { menjelaskan. }\end{array}$ & $\begin{array}{c}\text { Siswa } \\
\text { bertanya } \\
\text { hanya } \\
\text { memastikan } \\
\text { jawaban } \\
\text { mereka }\end{array}$ \\
\hline 4 & $\begin{array}{l}\text { Menjawab pertanyaan } \\
\text { yang diajukan guru }\end{array}$ & $0-8$ orang & 9-17 orang & $18-25$ orang & $25-32$ orang \\
\hline 5 & $\begin{array}{l}\text { Menguasai materi } \\
\text { yang diberikan guru }\end{array}$ & $\begin{array}{ll}\text { Nilai } & \text { LKS } \\
0-25 & \end{array}$ & Nilai LKS 26-50 & $\begin{array}{l}\text { Nilai LKS 50- } \\
75\end{array}$ & $\begin{array}{l}\text { Nilai LKS 76- } \\
100\end{array}$ \\
\hline 6 & $\begin{array}{ll}\text { Antusias } & \text { dalam } \\
\text { menjawab soal } & \\
\end{array}$ & $0-8$ orang & 9-17 orang & $18-25$ orang & $25-32$ orang \\
\hline 7 & $\begin{array}{ll}\text { Mengerjakan } & \text { tugas } \\
\text { tepat waktu } & \\
\end{array}$ & $0-8$ orang & 9-17 orang & $18-25$ orang & $25-32$ orang \\
\hline
\end{tabular}

Keterangan: skor minimum $=1$, skor maksimum $=4$.

Tabel 9. Hasil Pengamatan Proses Pembelajaran Siswa

\begin{tabular}{|c|c|c|}
\hline \multirow[t]{3}{*}{ Aspek yang dinilai } & \multirow{2}{*}{\multicolumn{2}{|c|}{$\frac{\text { Kelas Eksperimen }}{\text { Pertemuan }}$}} \\
\hline & & \\
\hline & Ke-2 & $\mathrm{Ke}-7$ \\
\hline Memperhatikan penjelasan guru & 2 & 3 \\
\hline Memperhatikan pertanyaan/tanggapan teman & 2 & 3 \\
\hline $\begin{array}{l}\text { Bertanya pada guru tentang materi yang kurang } \\
\text { dipahami }\end{array}$ & 2 & 4 \\
\hline Menjawab pertanyaan yang diajukan oleh guru & 2 & 3 \\
\hline Menguasai materi yang disampaikan oleh guru & 3 & 4 \\
\hline Antusias dalam menjawab soal di papan tulis & 2 & 3 \\
\hline Mengerjakan tugas tepat waktu & 2 & 3 \\
\hline Jumlah & 15 & 23 \\
\hline
\end{tabular}

Keterangan: $1=$ Kurang, $2=$ Cukup, 3 =Baik, $4=$ Sangat Baik

Kriteria: (Kurang: $7<x d^{\prime \prime} 14$ ), (Cukup: $14<x d^{\prime \prime} 21$ ), dan (Baik: $21<x d^{\prime \prime} 28$ ).

Siswa kelas eksperimen pada pertemuan kedua mencapai jumlah skor penilaian 15 , perolehan skor ini terletak pada interval $14<x$ d" 21 , sehingga pada pertemuan kedua siswa yang diajar dengan menggunakan teknik pola bilangan tergolong cukup aktif dalam proses pembelajaran. Pada pertemuan ketujuh skor penilaian siswa meningkat mencapai 23. Perolehan skor penilaian ini terletak pada interval $21<x d^{\prime \prime} 28$, sehingga pada pertemuan ketujuh keaktifan siswa dalam proses pembelajaran matematika pada materi operasi pembagian dengan menggunakan teknik pola bilangan tergolong baik. 
Teknik pola bilangan menyediakan suatu kolom yang memudahkan siswa untuk meletakkan antara yang dibagi, pembagi, hasil bagi serta sisa bagi. Kolom yang digunakan pada teknik pola bilangan dinamakan kolomatika, dengan kolomatika siswa akan mampu menghitung lebih mudah soal operasi pembagian, karena setiap kolom mempunyai kegunaan masing-masing sehingga siswa dengan mudah mampu meletakkan angka yang dibagi, pembagi, hasil bagi dan sisa bagi. Selain siswa mampu meletakkan hasil bagi, angka yang dibagi, pembagi dan sisa bagi dengan mudah, dengan kolomatika siswa lebih cermat dalam mengerjakan soal operasi pembagian, karena ada soal-soal tertentu apabila dikerjakan dengan teknik bersusun, siswa tersebut sering keliru dengan jawaban yang mereka temukan. Kekeliruan siswa dalam mengerjakan soal bisa teratasi dengan menggunakan teknik pola bilangan.

Hasil pengerjaan siswa untuk (4.592:7:8) dan (656:4:2) dengan teknik pola bilangan dapat dilihat pada Gambar 3.

Hasil analisis pada postes terlihat bahwa siswa yang nilainya rendah dikarenakan ada beberapa soal yang belum selesai dikerjakan oleh siswa. Perbandingan hasil pengerjaan siswa yang hapal perkalian dan kurang hapal perkalian dapat dilihat di Gambar 4.

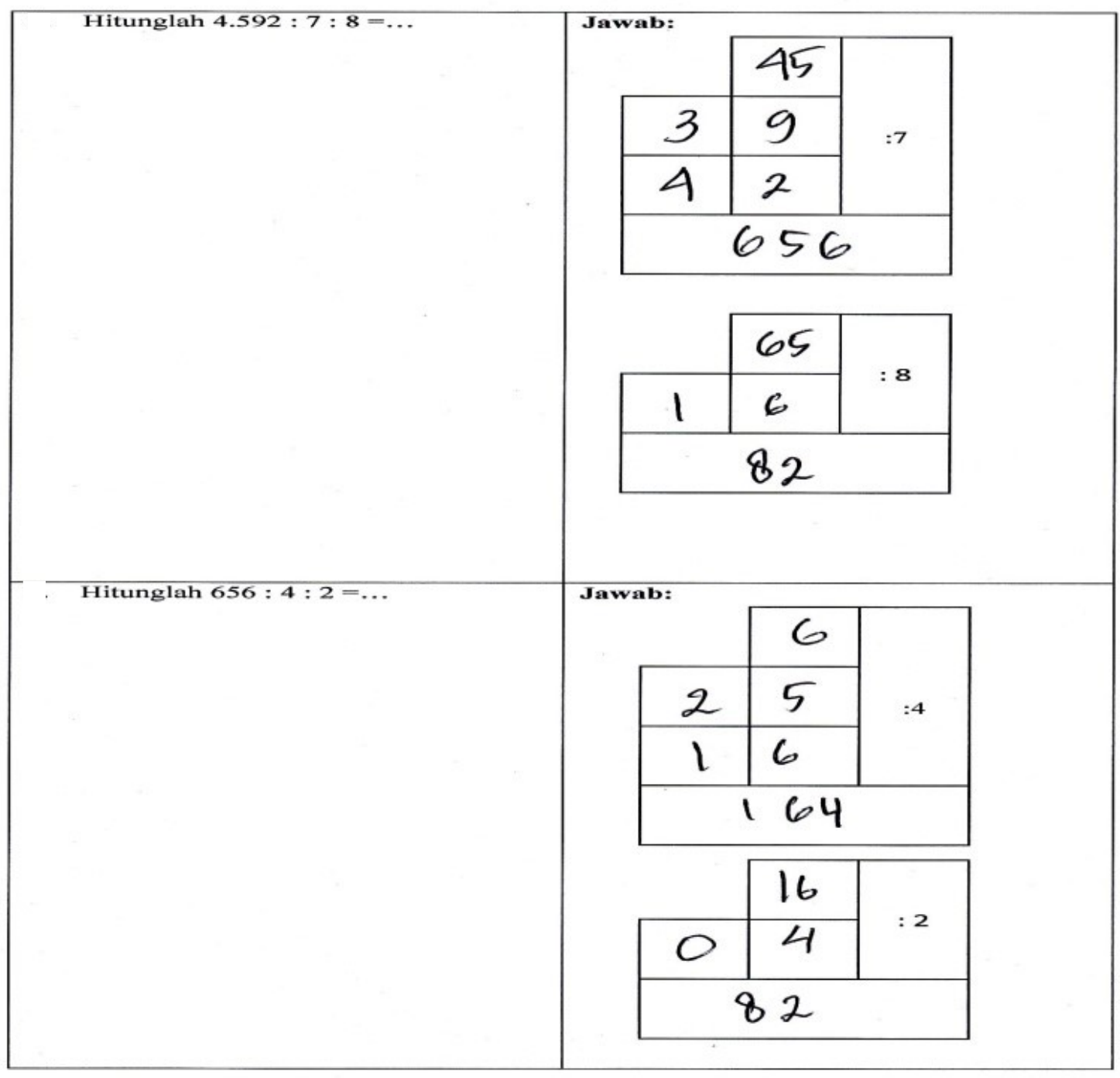

Gambar 3. Pekerjaan Kelompok pada LKS-4 

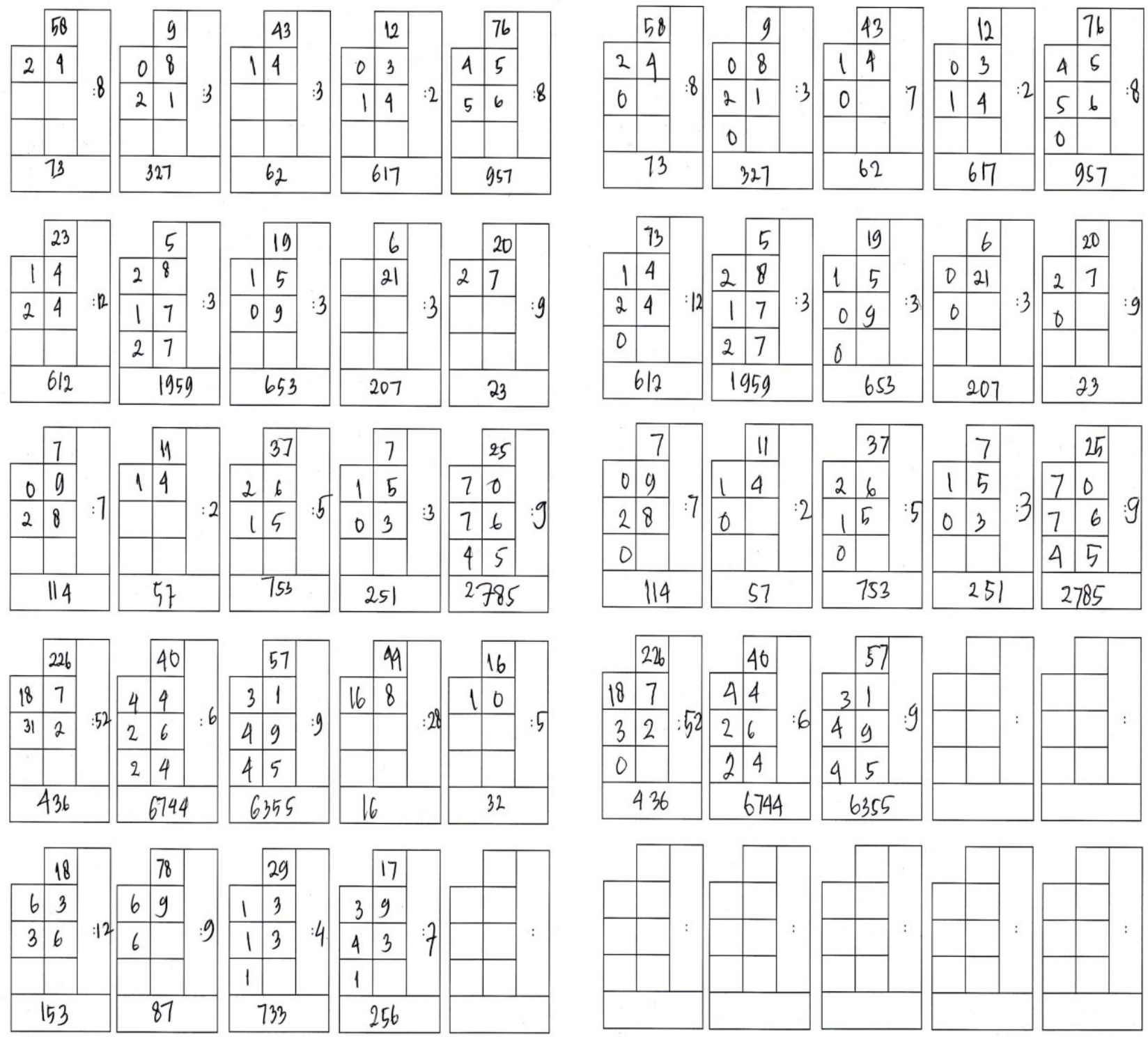

Siswa Selesai Menjawab Soal

Siswa Belum Selesai Mejawab Soal

Gambar 4. Perbandingan Hasil Pekerjaan Ujian Postes siswa

Hasil pengamatan selama penelitian mengungkapkan bahwa dalam menggunakan teknik pola bilangan terlihat bahwa siswa lebih bersemangat dalam proses pembelajaran. Hal ini disebabkan karena pada teknik pola bilangan memiliki tampilan pembagian yang menarik, serta siswa lebih cepat dan mudah dalam mengerjakan soal dengan memakai teknik pola, sehingga setiap siswa lebih percaya diri, tidak bosan dan semangat dalam mengerjakan soal operasi pembagian. Teknik pola bilangan siswa mampu meletakkan hasil bagi, dibagi, pembagi dan sisa bagi dengan lebih mudah, serta dengan meng- gunakan kolomatika siswa lebih teliti dalam mengerjakan soal operasi pembagian.

Temuan di atas, memperlihatkan bahwa teknik pola bilangan pada pokok bahasan operasi pembagian yang diterapkan pada proses pembelajaran dalam penelitian ini memberikan dampak positif yaitu siswa mampu meletakkan bilangan yang dibagi, pembagi, hasil bagi dan sisa bagi, serta siswa lebih cermat dalam menyelesaikan soal operasi pembagian. Siswa lebih percaya diri untuk menyelesaikan soal operasi pembagian dan lebih bersemangat. Temuan ini serupa dengan temuan penelitian Puji Gojali (2009) tentang 
Penerapan Teknik Berhitung Perkalian Polamatika Terhadap Hasil Belajar Matematika Siswa, yang mengungkapkan bahwa teknik polamatika dalam perkalian memberikan dampak positif terhadap hasil belajar siswa.

\section{Simpulan dan Saran Simpulan}

Dari hasil pengujian hipotesis dan bahasan hasil penelitian diberikan simpulan penelitian sebagai berikut. Pertama, kemampuan siswa dalam pembelajaran operasi pembagian bilangan cacah dengan menggunakan teknik pola bilangan di antaranya, siswa mampu meletakkan bilangan yang dibagi, pembagi, hasil bagi dan sisa bagi dengan mudah dan cepat dengan bantuan kolomatika dibandingkan dengan teknik bersusun. Di samping itu, siswa juga mampu menyelesaikan operasi pembagian secara cermat. Dengan bantuan kolomatika siswa lebih cermat dalam mengerjakan soal operasi pembagian serta kekeliruan siswa dalam mengerjakan soal lebih mudah diatasi. Hasil pengamatan siswa di kelas eksperimen, menunjukkan bahwa aktivitas siswa berada dalam kategori baik. Aktivitas selama pembelajaran dengan teknik pola bilangan meliputi: memperhatikan penjelasan guru, memberi pertanyaan/tanggapan teman, bertanya pada guru tentang materi yang kurang dipahami, menjawab pertanyaan yang diajukan oleh guru, menguasai materi yang diberikan guru, antusias dalam menjawab soal di papan tulis dan siswa mengerjakan tugas tepat waktu.
Kedua, hasil pengujian hipotesis dengan statistik uji-t menunjujkkan bahwa hasil belajar operasi pembagian yang diajar dengan menggunakan teknik pola bilangan lebih tinggi dibandingkan dengan hasil belajar matematika yang diajar dengan menggunakan teknik bersusun. Dengan demikian, terknik pola bilangan berpengaruh secara signifikan terhadap hasil belajar matematika pada pokok bahasan operasi pembagian.

\section{Saran}

Berdasarkan simpulan di atas, dapat diberikan saran-saran sebagai berikut.

Pertama, kepada para guru diharapkan mampu memberikan kesempatan kepada siswa untuk terlibat secara aktif melakukan operasi pembagian baik secara individu maupun kelompok, menyusun soal sendiri, mengemukakan gagasan, dan memecahkan masalah dengan menggunakan teknik pola bilangan. Kedua, Guru dapat menjadikan pembelajaran dengan teknik pola bilangan ini sebagai teknik alternatif dalam melaksanakan proses pembelajaran operasi pembagian dengan penyempurnaan lebih lanjut. Ketiga, model teknik pola bilangan diberikan dalam penelitian ini dapat dijadikan sebagai model belajar matematika secara mandiri guna meningkatkan kemampuan pemahaman konsep, penalaran, koneksi, komunikasi dan pemecahan masalah matematika yang berkaitan dengan operasi bilangan.

\section{Pustaka Acuan}

Gojali, Puji. 2009. Pengaruh Penerapan Teknik Berhitung Perkalian Polamatika Terhadap Hasil Belajar Matematika Siswa, Skripsi UIN Jakarta: Tidak Dipublikasikan.

Gunawan, Adi W. 2007. Cara Genius menguasai Tabel Perkalian, Jakarta: PT Gramedia Pustaka Utama. Premadi, Dradjad. 2007. Polamatika, Jakarta: PT Wahyu Media

Supatmono, Catur. 2009. Matematika Asyik, Jakarta: PT Grafindo.

Syah, Muhibbin. 2007. Psikologi Pendidikan dengan Pendekatan Baru, Bandung: PT Remaja Rosdakarya.

Trianto. 2009. Mendesain Model Pembelajaran Inovatif Progresif, Jakarta: Kencana. 